\title{
Science as a network and its applications in the analysis of the image of science in instructional/ teaching materials for the classroom ${ }^{1}$
}

\section{Ciência como uma rede e suas aplicações na análise de imagem da ciência em materiais auxiliares para a sala de aula}

\author{
DIANA FARÍAS \\ Universidad Nacional de Colombia | Bogotá, Colombia \\ AGNALDO ARROIO \\ Universidade de São Paulo | USP
}

\begin{abstract}
The inclusion of historical content in science classes has been widely discussed even before science education emerged as a discipline. In this paper we aim to show that when science is understood as a complex network, network analysis can be used to identify and strengthen elements that make up its historical narrative. This narrative can then be introduced at school in order to communicate a more contextualized, human, and connected image of science more akin to scientists' science. First, we show some applications of a methodology based on Bruno Latour's model of science circulation in the analysis of various classroom materials: textbooks, documentaries, movies, and biographies. Then, based on the results of these applications we discuss the model's vast potential for identifying various aspects that could be strengthened in the classroom, thus providing the possibility of writing a more" personalized" history of science, one more in tune with teachers' and students' varying interests and that more closely resembles what scientific activity actually means in the contemporary world.
\end{abstract}

Keywords Bruno Latour's circulation of science model - science as a network - history of science in science education - social studies of science.

RESUMO A inclusão de conteúdos históricos nas aulas de ciências tem sido amplamente discutida mesmo antes da educação científica como uma disciplina. Neste artigo vamos mostrar como a compreensão da ciência como uma rede complexa permite o uso de análise de rede para identificar e fortalecer os elementos para criar uma narrativa histórica da ciência que pode então ser introduzido na escola para comunicar uma imagem da ciência mais contextualizada, humana e conectada mais consistente com a ciência dos cientistas. Primeiro, vamos mostrar alguns exemplos de aplicação de uma metodologia baseada no modelo de como a ciência circula de Bruno Latour com a análise de diversos materiais encontrados na sala de aula: livros didáticos, documentários, filmes e biografias. Em seguida, com base nos resultados desta aplicação discutimos o vasto potencial do modelo para a identificação de vários aspectos que poderiam ser reforçados na sala de aula, proporcionando assim a possibilidade de escrever uma história mais "personalizada" da ciência, mais em sintonia com os professores e alunos e seus diferentes interesses e que mais se assemelha ao que a atividade cientifica significa no mundo contemporâneo.

Palavras-chave modelo de circulação da ciência de Bruno Latour - ciência como uma rede - história da ciência no ensino de ciências - estudos sociais da ciência. 


\section{Introduction}

One of the most important issues in science teaching research is the debate concerning the ends and aims scientific education should currently strive for, a debate that places scientific competition and scientific literacy face to face, that is to say knowledge about science vs. knowledge about science culture ${ }^{2}$. The History and Philosophy of Science (HPS) approach plays a significant role as mediator in this debate, since it helps us to see science as the product of an individual as well as a social construction.

The inclusion of the History of Science in science classes has nevertheless been a widely debated issue and despite the clear advantages that its inclusion offers to Science Education at the cognitive, emotive/individual and sociocultural level these discussions have failed to reach any agreement. On a cognitive level, science concepts could be more easily understood if they were shown in context. On an emotive/individual level, if students as well as teachers were able to identify themselves with people who actually do science it could mean an increase in students' motivation to study it. On a sociocultural level, science learning would also be positively influenced if the scientific undertaking also shows itself as part of society and culture.

Those who critique in favor of the inclusion of historical contents in Science Education mainly point to the relevance of historical contents introduced in science classes and teaching materials. Such critiques point out that in the majority of the cases, what is taught at school is not real history, but pseudo-history ${ }^{3}$. In this pseudo-history the stories are always about the same scientists ${ }^{4}$, in addition, they are not useful for transmitting scientific concepts, historically incompetent, and inadequate from the Nature of Science point of view ${ }^{5}$, not to mention the irrelevancy of their content ${ }^{6}$, to cite just a few.

These critiques insist on pointing out certain aspects when introducing historical contents: that they 1) not be limited to dates or facts to be memorized; 2) keep in mind the stories of those who have often been left out (women, minorities, local contributions); 3) avoid accounts of "progress" built only retrospect and overlooking all the mistakes that could have and were probably been made (Whig narratives); 4) pay attention to controversies; and 5) make reference to original sources, amongst others ${ }^{7}$.

Such criticism could be directly associated to the lack, in our own discipline, of cases in classrooms that explicitly show a weak relationship between research lines in Nature of Science and HPS. These two lines appear to have parallel agendas, but, when looked at in detail, show a number of shared elements that when put together could provide science classrooms with a more complex understanding of scientific activity.

In this paper, our aim is to show how contemporary perspectives in the Social Studies of Science can allow us to tell an account of science at school, which is simultaneously sociological and historical, and that would favor a more active role for students and teachers, and that above all, would transmit an idea of a more dynamic, unfinished and contingent science, in agreement with the values of our time. To this end, we used the model of science circulation proposed by Bruno Latour ${ }^{8}$, in which science is understood as a complex network where different actors are connected throughout time. In this way, through various classroom materials, we can explore the different images of science and scientists that could contribute alternative narrative contents to science learning.

Since our proposal is based in great part on the application of one of the ideas of the French sociologist, Bruno Latour, his circulation of science model mentioned above, it's important for us to point out some aspects of how this model emerged. In 1973 Bruno Latour worked as an ethnographer in Roger Guillemin's laboratory (the same Guillemin who received the Nobel Prize in medicine in 1977) at the Salk Institute in La Jolla, California. There, he took on the task of closely following and documenting what the scientists there did every day. This experience led him to propose that scientific activity extended outside the walls of the laboratory and also, that a large quantity of actors intervened in the work of the supposed "solitary" Doctor Guillemin, actors that Latour later decided to describe, order and comprehend. 
Within this model the classic image of a science based on discoveries made by scientists alone in their laboratories, that is, without context, becomes an image made up by a kind of collage of those actors, connected in space and time, an image that would allow scientific facts to circulate and scientific work to be known not only by the scientific community, but by the general public. Latour suggests that science is a complex network where the interaction of said actors can be understood in terms of the following five categories:

Mobilization of the world, laboratories and research centers are not the only sites where science is done, the outside world is also another place, where expeditions, surveys, instruments, and equipment are of special interest, in a kind of tracking of the logistics of scientific activity.

Autonomization, which requires exploring how a researcher surrounds himself with colleagues, how a discipline, a profession or an invisible school of scientists becomes independent and creates its own criteria of evaluation and abilities, a foundation of all relationships between researchers; this exploration implies tracking professions and disciplines as well as the history of scientific institutions.

Alliances, which refers to abilities needed to spark interest in groups apparently unrelated to science, but which nevertheless result fundamental to the development of scientific activity, groups such as the state, the military, industry, teaching systems, etc.; this implies tracking "technocracy" and "bureaucracy", amongst others.

Public Representation, which refers to the process of the socialization of the objects of science en masse, to the capacity of scientists to mobilize these objects away from their colleagues, politicians or funding agencies involved in a specific scientific "project" (from the previous two spheres) and make their object known to the public.

Finally, Latour calls the fifth category "links", elements that group and keep all the other previous elements of the other four spheres together. They include concepts, theories, laws, hypotheses, models, constants, formulae, principles, equations and phenomena, established by scientists and involved in mobilizing science in circulation. These are the elements that bring the others together and around which the other four categories move. From a scientificist point of view these would be the only actors worth talking about; in a classic scientific discourse what matters are the concepts, the context is merely external. Unlike them, in Latours network these actors are central to the discourse, but insofar as they serve as bridges for other actors.

Additionally, it is typical of Latour's work that around these other actors, there are what he calls non-humans who take on a kind of special protagonist role. According to Latour, non-humans include all the real world entities that emerge as products of scientific activity and whose identity refers to its practice as well as to the relationships they can establish with other actors. Thus, for Latour, atoms, viruses, sea sponges, etc. have "agency"; they can change or determine the course of science (for a more detailed explanation see Chapter 5, The Historicity of Things. Where were microbes before Pasteur? in Pandora's Hope).

This model of science shows that science is a highly complex activity, a vision completely opposite to that of school science, which is basically centered on concepts, unaware of the role of the other actors in the production and circulation of scientific knowledge ${ }^{9}$. In this paper we assumed the hypothesis that in the face of the schools' failures to transmit a more humanized image of science, as witnessed in traditional school materials (mainly textbooks), we can make use of other materials such as documentaries, biographies, films, amongst others. These materials do say something about those otherwise invisible and absent actors. In this paper we used the model of the circulation of science to characterize the science present not only in those materials, but also in traditional textbooks. Our aim is to analyze with whom and how these different actors socialize, and hence, also what they reflect about scientific activity and how they can be introduced in the classroom in order to complement traditional materials when talking about the history of science. 


\section{Methodology}

Our methodology is based on the analogy of science as a network. What we do is none other than identify actors, find out with whom they associate, and represent this as a network. Based on the model previously presented, we have kept track of the presence of all actors belonging to the five previous categories according to the characterization of the five attributes as shown in Table 1. This characterization allows us to be very specific when it comes time to use the model for didactic material analysis. It was designed by Farías to analyze textbooks ${ }^{10}$ and we have used it to analyze films ${ }^{11}$ and biographies ${ }^{12}$ as will be shown in what follows.

First, a list of actors is made; they can be from a textbook, a biography, a film, a documentary, etc. Using graph theory terminology, actors correspond to nodes $\mathrm{j}_{\mathrm{i}}$ and their relationships can be represented in a $\mathrm{j} x \mathrm{j}$ matrix where the relationships between pairs are described by a " 1 " and their absence by a " 0 ". This matrix is used as the input for network rendering and visualization. In our case we used Gephi 8.01, an open-software designed by Gephi Consortium ${ }^{13}$.

Table 1. Categories and attributes from the science circulation model used for characterizing different actors (nodes)

\begin{tabular}{|ll|}
\hline Category & Attributes \\
\hline Mobilization & Instruments, laboratories, equipment, instruments, places \\
\hline Autonomy & Associations, institutions, professional groups \\
\hline Funding & Funds, sponsors, scientific support, political support ... \\
\hline Representation & Relations with the layman \\
\hline Links & Concepts, theories, laws, hypotheses, constants, formulas, principles, models \\
\hline Non-humans & Entities from the material world, which have agency and can form relationships with other actors \\
\hline Humans & Scientists, philosophers, poets, politicians... \\
\hline
\end{tabular}

\section{Results}

In this paper our aim is to show the potential of viewing science as a network; it could bring other elements to the table that would transform the image of science in the classroom. We based our work on the main findings of the analysis of different materials utilized in the classroom using the previously described methodology. In the last three years we have analyzed textbooks ${ }^{14}$, biographies ${ }^{15}$, documentaries and films ${ }^{16}$. Our aim is to present and compare these different materials.

Diana Farías ${ }^{17}$ used the aforementioned methodology to analyze the chapters on atomic structure of 60 textbooks published in Spain between 1865 and 2010, one of these analyses is discussed in this paper. Farías and Arroio ${ }^{18}$ used this same methodology to analyze the notions of science and scientists that can be developed through the use of biographies, a study from which we borrow the case centered on an episode from a biographical documentary on the life of Marie Curie. The last case is taken from Arroio and Farías ${ }^{19}$, where they analyzed the possible contributions of cinema to understanding how scientists and science works. From this study we focused on the movie Fat Man and Little Boy, which is about Robert Oppenheimer and the Manhattan Project. ${ }^{20}$ In the Appendix we show their corresponding networks. Table 2 shows a summary comparing the results of the three previous cases. 


\begin{tabular}{|c|c|c|c|}
\hline Caregory & Textbooks ${ }^{21}$ & Biography ${ }^{22}$ & Movie $e^{23}$ \\
\hline Mobilization & $\begin{array}{l}\text { Laboratories, the places from } \\
\text { which science emerges, are } \\
\text { absent. }\end{array}$ & $\begin{array}{l}\text { It's important to show the } \\
\text { trajectories of scientists, } \\
\text { the places and laboratories } \\
\text { where they work, etc. }\end{array}$ & $\begin{array}{l}\text { There is a strong presence of } \\
\text { equipment and laboratory instruments. } \\
\text { Science is shown displaced from a } \\
\text { central location making it possible to } \\
\text { see how it moves between universities } \\
\text { and laboratories. }\end{array}$ \\
\hline Autonomy & $\begin{array}{l}\text { In some introductory } \\
\text { chapters about what science } \\
\text { is associations like IUPAC or } \\
\text { IUPAP are mentioned. }\end{array}$ & $\begin{array}{l}\text { Associations appear as } \\
\text { collectives relevant to the } \\
\text { life of scientists to the point } \\
\text { that they can influence their } \\
\text { behavior. }\end{array}$ & $\begin{array}{l}\text { Universities appear and play a central } \\
\text { role, the image of working groups and } \\
\text { scientific discussion is also mentioned. }\end{array}$ \\
\hline Funding & $\begin{array}{l}\text { The relationships with others } \\
\text { that scientists need to make } \\
\text { in order to finance their work } \\
\text { are not talked about. }\end{array}$ & $\begin{array}{l}\text { Funding is mentioned, } \\
\text { especially with regards to } \\
\text { prizes, especially } \\
\text { the Nobel prize. }\end{array}$ & $\begin{array}{l}\text { Funding is mentioned repeatedly } \\
\text { through how the U.S. government has } \\
\text { invested in the project and how the } \\
\text { scientist's has to end it according to } \\
\text { a strict schedule established by the } \\
\text { sponsor. }\end{array}$ \\
\hline Representation & $\begin{array}{l}\text { Scientists' relation to their } \\
\text { lay public is not mentioned. }\end{array}$ & $\begin{array}{l}\text { There is no attention placed } \\
\text { on this relationship. }\end{array}$ & This relationship is not mentioned. \\
\hline Links & $\begin{array}{l}\text { Links are the protagonists } \\
\text { in science textbook, they } \\
\text { exist even without being } \\
\text { connected to other actors. }\end{array}$ & $\begin{array}{l}\text { Links are not protagonists } \\
\text { since what is relevant is } \\
\text { characterizing the context in } \\
\text { which scientists live. }\end{array}$ & $\begin{array}{l}\text { Links are not protagonists, there are } \\
\text { some references to them, but they do } \\
\text { not play a major role in the story. }\end{array}$ \\
\hline Non-humans & $\begin{array}{l}\text { Non-humans are important } \\
\text { as the axis of discovery, the } \\
\text { model that defines what } \\
\text { scientific activity is. }\end{array}$ & $\begin{array}{l}\text { They are important when } \\
\text { it comes to talking about } \\
\text { discoveries, but their agency } \\
\text { is not mentioned. }\end{array}$ & $\begin{array}{l}\text { The bomb, a non-human, built by the } \\
\text { scientific work is central to the plot of } \\
\text { the film. It also changes the trajectory } \\
\text { of research continuously; hence, its } \\
\text { agency is undoubtedly large. }\end{array}$ \\
\hline Humans & $\begin{array}{l}\text { Humans can be left out of } \\
\text { the narrative, but when they } \\
\text { are mentioned it is often } \\
\text { in an idealized way, and } \\
\text { generally shown to work } \\
\text { alone. }\end{array}$ & $\begin{array}{l}\text { Humans are the central axis } \\
\text { of science and scientific } \\
\text { activity revolves around } \\
\text { them. }\end{array}$ & $\begin{array}{l}\text { Humans appear as physicists working } \\
\text { collectively, highlighting the importance } \\
\text { of teamwork, but at the same time } \\
\text { the image of the genius. Scientists are } \\
\text { also shown with other humans such as } \\
\text { military officers, family and friends. }\end{array}$ \\
\hline
\end{tabular}

Initially, networks that represent scientific activity in school textbooks are characterized by a complete predominance of links and almost a total lack of presence of other elements such as instruments, laboratories, and institutions, amongst others. This leads us to ask, where and how is science carried out in these narratives? The leading actors in this narrative are the experiments and models, although the texts rarely offer an encompassing description of how they are carried out.

These narratives can be seen as "black boxes" 24 in which, taking Thomson's atomic model as an example, this model is reduced to a schematic drawing representing the atom, its characteristics in terms of their location inside the atom, subatomic particles and how it is replaced by a new model; some textbooks don't even mention Joseph J. Thomson. This type of rhetoric represents a science understood as a collection of finished products, those concepts that make up the index or table of contents and through which textbooks are structured, and in the end, a reflection of the lists that also make up the curricular program ${ }^{25}$. According to Latour, this blackboxing guarantees a "more technical", "more solid", "more stratified" and "less public" knowledge ${ }^{26}$, thought of as more apt for the structure of the transmission of knowledge proper to school. 
Moreover, textbooks never talk about funding nor of public representation, and in this way it remains separate from any kind of "external" references, thus, textbooks close themselves off from a variety of elements in the sphere of what is considered non-scientific: influences and interests. As for the so-called non-human actors, they are socialized, at best, thanks to the role of scientific fields, but at the expense of links such as theories, hypotheses, or models. However, in many of these cases non-humans are independent from scientists and textbooks are left without the people who do science.

What we can say about the scientists in these textbooks is that they are at a disadvantage. In the networks they appear at the periphery (and generally connected to only one node), without context, without connections that could manifest the sociocultural conditions of the period in which they lived, spatiotemporally delocalized - without any connections related to their time or place, isolated from each other and in many cases also mythified - described with those hagiographic narratives that some Science Education researchers have greatly criticized.

On the other hand, when we analyzed other materials and resources (biography and film whose networks appear in the Appendix), there was a notable shift in the main axis of the narrative. The scientists moved from the periphery toward the center, taking the place of the most important nodes within the networks and appearing as highly connected to: other scientists, places, institutions, laboratories, experiments, links and non-humans. These last two, however, disappear in the films, where it is more important to contextualize and give meaning to a story where scientists are the obvious protagonists. Scientists appear as widely contextualized thanks to those connections mentioned previously, and in this way it is possible to understand the age in which they lived in as more rich socio-cultural contexts. A different type of history is shown, a narrative history where the historical event is more important than the history of the scientist himself or the accuracy of the story that is told.

It's clear that the narratives of the science from textbooks, biographies and movies reflect very different images of science. One is a school science that, unfortunately, has blindly focused its narrative merely on concepts, leaving behind many crucial elements that are indispensable to scientific activity (instruments, laboratories, alliances, etc.). When these historical aspects are part of the narrative, textbooks tend to track the history of a discovery, where it is important to describe the history of a link, for example the idea of the atomic model. Generally, these historical aspects are used to give credibility to the idea that science progresses, supporting the idea that in the history of science correct concepts replace erroneous ones as time advances.

The science of the documentary is centered on the person, instead of links, an aspect that has been criticized from the moment that biography as a genre appeared and turned the history of disciplines and ideas into the history of scientists ${ }^{27}$.

Finally, the history of science that the film transmits tries to recreate the facts, basing itself on primary sources not only to talk of scientists and concepts, but of "history as it really is".

The number of discussions centered on the inclusion of historical aspects reflects in some way the division of these three types of histories. Some authors have argued against including the History of Science in the classroom because they consider that the stories that are told are often idealized and often only show scientists as heroes. Yet, when the narratives are centered on people the positivist discourse from textbooks can be refuted, the one that has all the supposed objective aspects, certainties, truths and finished facts. The history of ideas appears in school as a list of dates in which, as mentioned previously, it is the most relevant events to the solidification of scientific concepts what is described, whereas narrative history of scientific events is never present in classic teaching materials.

Faced with the dilemma of choosing between following the history of scientists (hagiography), the history of concepts (history of ideas) or the history of scientific events (narrative history) a viewpoint from the Social Studies of Science, which instead refers to practice, to the task of science as a construction, is a viable alternative. In school this idea of science as a construction can be approached when introducing two elements: experiments and discoveries.

An outstanding feature in all the analyzed materials is the role that discovery plays in a certain event, which in a specific moment and place brings to light a non-human, an actor who was previously absent from the history of science. 
Hence, for example, Marie and Pierre Curie discover Polonium and Radium, two new elements that already existed in nature, but that had not yet existed for the scientific community.

Ana Isabel Pereira and Filmoena Amador ${ }^{28}$ have already highlighted the importance of discovery in a study in which they analyzed fifth grade school natural science manuals. For these two researchers, the use of the verb "discover" could be associated with an author's intent to show scientific knowledge as more accessible. Nevertheless, in our analyses of textbooks and other resources these narratives share a characteristic, generally a discovery is expressed as a date and an other (almost always a non-human) which is discovered, but rarely is it accompanied by a description. Thus, discovery becomes a discursive element that also mythifies scientific activity, as has been pointed out by Latour and Woolgar ${ }^{29}$ when they explain how the solidifying of a scientific fact leaves out the details of the process involved in its construction, including the "glorious" instant of discovery.

From another viewpoint, experiments are agents that socialize a large quantity of elements: scientists, laboratories, institutions, instruments, links and non-humans. Even so, a history based on experiments still makes for a poor history and still makes reference to discoveries as if they were the most crucial aspect, which implies a certain level of idealization (the study of historical experiments has played an important role in Science Education, for example ${ }^{30}$, amongst others). Nonetheless, if we want to change the way in which science is written about, to go from texts about "blackboxed", finished products to texts that talk about processes, contingencies, errors or controversies, these discoveries and experiments would become elements favorable for talking about how science is carried out, even more if the contents destined for the classroom are based on the accounts that scientists themselves give of these.

\section{Didactic implications}

The analogy of science as a network brings to light the presence or absence of different actors and the relationships that should be strengthened or introduced in the account of science at school, with the purpose of contextualizing and spatial-temporally localizing it, that is, with the purpose of writing a History of Science worthy of that name. What is interesting about this approach is that after starting to track an actor in these networks, no matter where the tracking starts, one often arrives at different connections and new trajectories, in the same way that historians can arrive at different histories depending on the aspects they want to emphasize.

This way of looking at science shows, as mentioned previously, its complexity, dynamism, the possibility of making different aspects relevant without losing sight of concepts, since they are, as Latour says, what joins and connects all the other actors. This creates the possibility of having an image of science closer to the science that is actually done in research centers and laboratories worldwide.

A "historical reconstruction" of this kind, where an actor is established in space and time (for example, Ernst Rutherford - 1908) allows for the exercise in which teachers and students can take on the task of finding other actors and following the trajectory of their networks. This "tracking down" can result more simple with access to different sources of information (including original letters and papers) available online. Searching on the Internet has the advantage of being one of the things that students already like to do, motivated by the challenge of finding information there.

An additional advantage is being able to reevaluate the role that traditionally has been given to scientists in science teaching materials (textbooks especially), making them the epicenter of networks.

This goes hand in hand with the idea that a traditional perspective of school science anchored in concepts (that are actually disconnected from recent scientific advancements) shows a need to recognize that textbooks should not be the only source of information in the classroom. It is also necessary to use extracurricular materials that can guide teachers interested in talking about the history and nature of science in their classes, the same teachers who are constantly complaining about the lack of materials to help them realize these interests. 
This simple way of analyzing the way in which science is talked about in different materials can be used by teachers to help them decide how and where additional elements that do talk about that absent science can be introduced alongside classic contents centered on concepts. In this way, the teacher is more autonomous; they can rewrite a "personalized" history for their class, a history where those usually absent elements are found, writing a history that is not limited to what the textbook says. This would be a history that reflects not only the dynamism of science, but also its teaching.

A science teacher that decided to include historical aspects in their class should not only be able to select from an infinite variety of teaching materials to which they have access today, but should understand that the relevancy and importance of some of them obeys a history in which terms such as popularization (which is very close to biographies) or humanization will always be under scrutiny faced with an ideal science centered purely on the cognitive.

What the three examples here discussed show is that more than answers or certainties, we are left with a series of questions that could enrich our classic discussions on the pertinence of the History of Science in the science classroom:

1. The need to recognize science as a process and not as a sum of finished products.

2. The need to recognize science as a highly complex activity in which a large number of actors of diverse nature and connected through space and time take part in.

3. The need to recognize the importance of the history and nature of science and the fact that at school these should go beyond the limited information found in textbooks.

4. The need to demystify the "neutrality" and "authority" of the so-called "official history" of science as a first daring step to "re-construct" the narrative of science as a process.

5. And finally, that the version of the scientific narrative meant for school be humanized in all senses, a first stage without which we will not be able to strive for a human didactic of science.

\section{Appendix}

Three examples of networks that show how science circulates within different materials that might be found in the classroom. Each color represents a group of attributes and the size of each node the number of connections it makes with others.

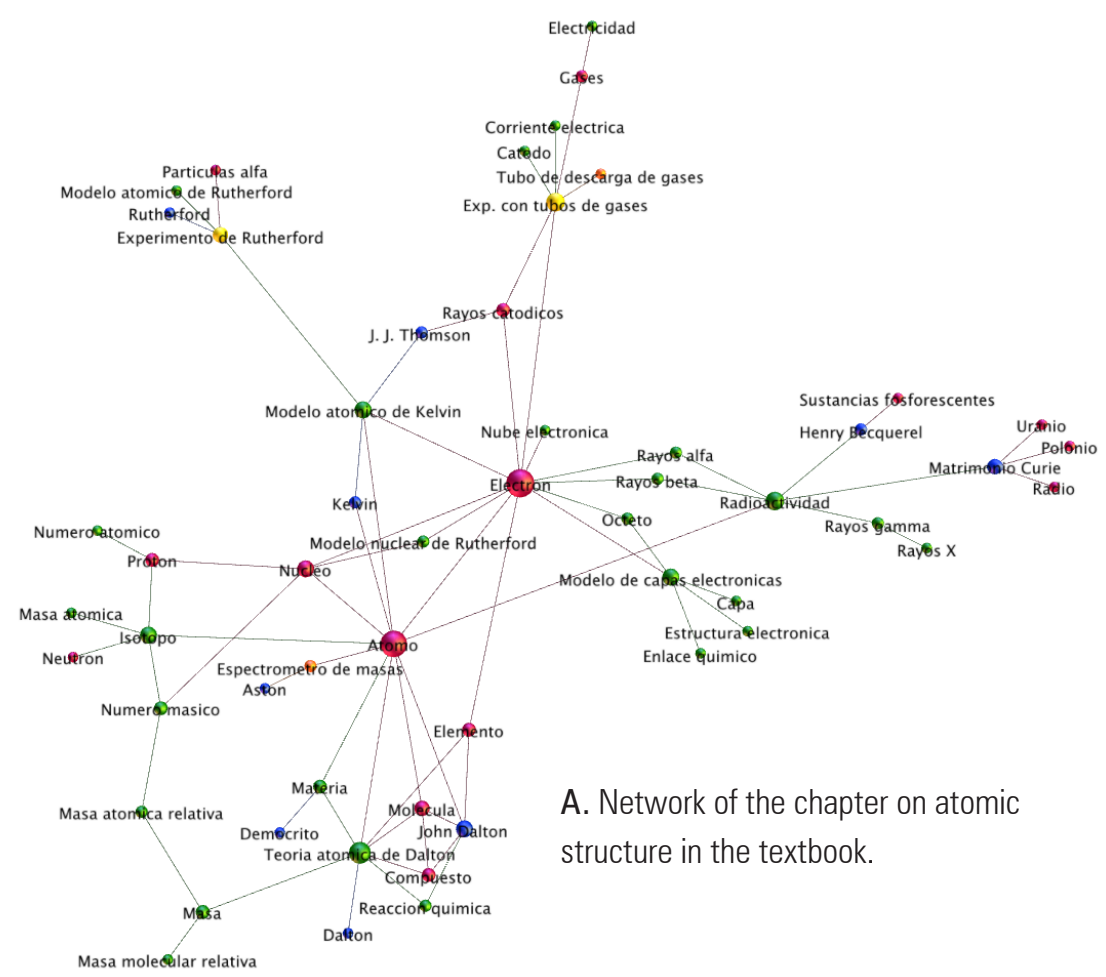


B. Network of the animated documentary about the life of Marie Curie.

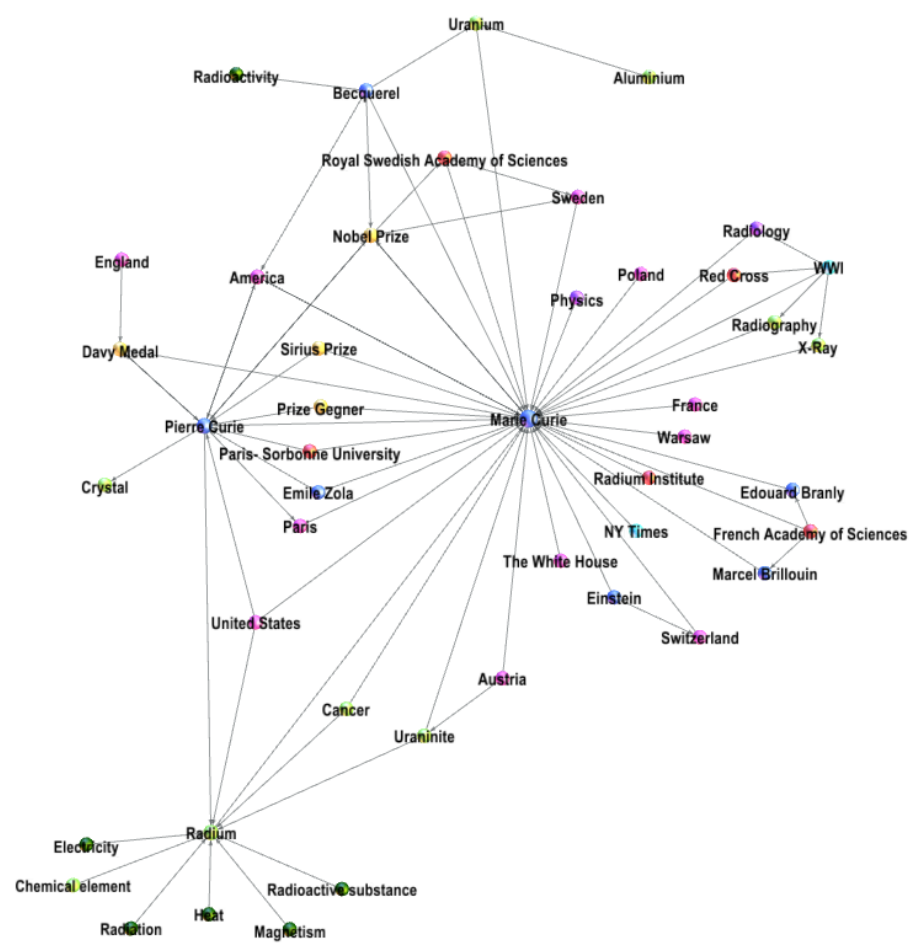

C. Network of a 25-minute segment of the film Fat Man and Little Boy.

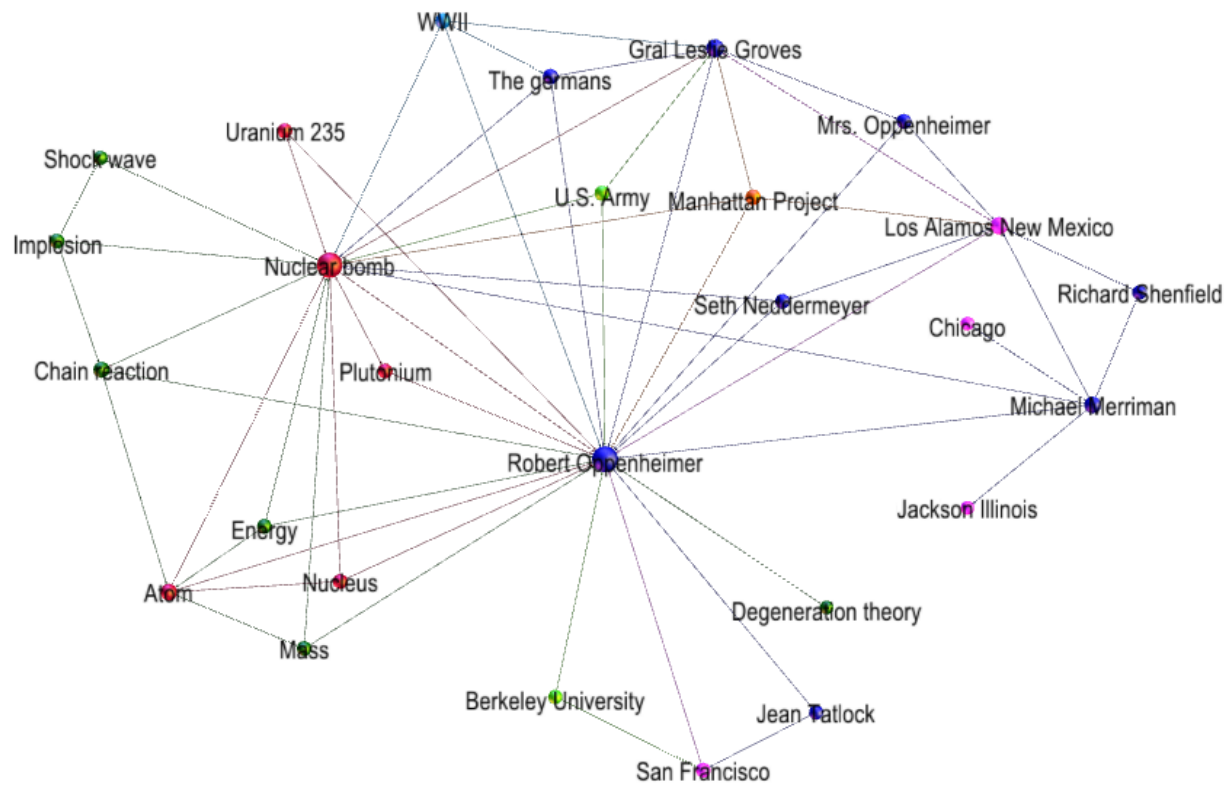




\section{Notes and references}

Diana Farías. Grupo de investigación en enseñanza de la química. Departamento de Química, Universidad Nacional de Colombia, Colombia. E-mail:dmfariasc@unal.edu.co.

Agnaldo Arroio. Departamento de Metodologia do Ensino e Educação Comparada. Faculdade de Educação, Universidade de São Paulo, Brasil. E-mail: agnaldoarroio@yahoo.com.

1 We would like to thank every single one of our colleagues who participated in the different discussions at IHPST-LA 2012 and ESERA 2013, where the ideas that support this paper were presented.

2 MATTHEWS, Michael. Time for science education: How teaching the history and philosophy of pendulum motion can contribute to science literacy. New York: Kluwer Academic/Plenum Publishers, 2000.

3 ALLCHIN, Douglas. Pseudohistory and Pseudoscience. Science \& Education, v.13, n. 3, p. 179-195, 2004.

4 KOLSTØ, Stein. D. Science Education for Democratic Citizenship Through the Use of the History of Science. Science \& Education, v. 17, n. 8-9, p. 977-997, 2008.

5 HEERING, Peter; KOWALSKI, Sebastian. Not Out of the Blue: The Genesis of Modern Textbooks Descriptions of Historical Experiments. In: INTERNATIONAL CONFERENCE OF THE EUROPEAN SOCIETY FOR THE HISTORY OF SCIENCE, 4, 2010, Barcelona. Proceedings. Barcelona: Societat catalana d'Història de la Ciència i de la Tècnica, 2012, p. 72-77.

6 KINDI, Vasso. Should Science Teaching Involve the History of Science? An Assessment of Kuhn's View. Science \& Education. Dordrecht, v. 14, n. 7-8, p. 721-731, 2005; KIPNIS, Nahum. The "Historical-Investigative" Approach to Teaching Science. Science \& Education, v. 5, n. 3, p. 277-292, 1996; IZOUIERDO, Mercé. Relación entre la historia y la filosofía de la ciencia y la enseñanza de las ciencias. Alambique. Barcelona, v. 8, n. 1-21, p. 7-21, 1996; ELKANA, Yehuda. Science, Philosophy of Science and Science Teaching. Science \& Education, v. 9, n. 5, p. 463-465, 2000.

$7 \quad$ KING, Bruce. Beginning teachers' knowledge of and attitudes toward history and philosophy of science. Science Education, v.75, n.1, p. 135-141, 1991; PADILLA, Kira; FURIO-MAS, Carles. The Importance of History and Philosophy of Science in Correcting Distorted Views of 'Amount of Substance' and 'Mole' Concepts in Chemistry Teaching. Science \& Education, v.17, n.4, p. 403-424, 2008; MUÑOZ, Rosa; BERTOMEU, José. La historia de la ciencia en los libros de texto: la(s) hipótesis de Avogadro. Enseñanza de las ciencias, v.21, n.1, p. 147-159, 2003; RODRíGUEZ, María; NIAZ, Mansoor. How in spite of the Rhetoric, History of Chemistry has been ignored in presenting Atomic Structure in Textbooks. Science \& Education, v.11, n.5, p. 423-441, 2002; KALMAN, Calvin. The Need to Emphasize Epistemology in Teaching and Research. Science \& Education, v.18, n.3-4, p. 325-347, 2009; KRAGH, Helge. A sense of history: History of science and the teaching of introductory quantum theory. Science \& Education, v.1, n.4, p. 349-363, 1987; MONK, Martin; OSBORNE, Jonathan. Placing the History and Philosophy of Science on the Curriculum: A Model for the Development of Pedagogy. Science Education, v.81, n.4, p. 405-424, 1997.

8 LATOUR, Bruno. Pandora's hope: Essays on the reality of Science Studies. Cambridge: Harvard University Press, 1999.

$9 \quad$ LATOUR, op. cit., 1999.

10 FARÍAS, Diana. M. Teoría, estructura y modelos atómicos en los libros de texto de química de educación secundaria. Análisis desde la sociología de la ciencia e implicaciones didácticas. 422 f. Tesis (Doctorado en Educación) - Facultad de Formación del Profesorado, Universidad de Barcelona, Barcelona, 2012.

11 FARÍAS, Diana. M.; ARROIO, Agnaldo. The role of biographies in chemistry education and its contribution to understanding how scientists and science works. Problems of Education in the 21st Century. Siauliai, v. 50, p. 14-22, 2012.

12 ARROIO, Agnaldo; FARÍAS, Diana. Possible Contributions of Cinema in Natural Science Education to Understand How Scientists and Science Works. Problems of Education in the 21st Century. Siauliai, v. 37, p. 18-28, 2011.

13 https://gephi.org/ [accessed on July 24-2014]

14 KING, op. cit., 1999.

15 PADILLA; FURIO-MAS, op. cit., 2008.

16 MUÑOZ; BERTOMEU, op. cit., 2003.

$17 \quad$ FARÍAS, op. cit., 2012.

18 FARÍAS; ARROIO, op. cit., 2012.

19 Idem.

20 The datasheets of the analyzed materials are as follows: 1. Textbook: Elementos de química con rudimentos de análisis químico. Zaragoza: Editorial Luis Vives S.A. 194-. 2. Animated documentary episode: Episode 22 of the animated series "Así es la vida. Los inventores: Marie Curie" (1994). Director: Albert Barillé. Available at <http://www.youtube.com/watch?v=HjOJhllheHY> . Accessed on August 3, 2013. 3. Movie: Fat Man and Little Boy (1989). Director: Roland Joffé. Cast: Paul Newman as General Leslie R. Groves and Dwight Schultz as J. Robert Oppenheimer.

21 FARÍAS, op. cit., 2012.

22 FARÍAS; ARROIO, op. cit., 2012.

23 FARÍAS; ARROIO, op. cit., 2011.

24 Farías, Diana. M. School science and scientist's science: blackboxed sciences. In: IHPST 2013 CONFERENCE, 13, 2013, Pittsburgh. Proceedings. Pittsburgh: IHPST, 2013. Retrieved in: <http://archive.ihpst.net/2013-pittsburgh/conference-proceedings/> . Accessed on: 20 nov. 2013.

25 IZQUIERDO, Mercé. Estructuras retóricas en los libros de ciencias. Revista de Investigación e Innovación Educativa. Madrid, v. 36, p. 11-34, 2005; KNAIN, Erik. Ideologies in School Science Textbooks. International Journal of Science Education. London, v. 23, n. 3, p. 319-329, 2001.

26 LATOUR, Bruno. Science in action. How to follow scientist and engineers through society. Cambridge: Harvard University Press, 1987. 
SÖDERQVIST, T. A New Look at the Genre of Scientific Biography. In: SÖDERQVIST, T. (Ed.) The History and Poetics of Scientific Biography. Ashgate: Cornwall, 2007, p. 1-15.

28 PEREIRA, Ana Isabel; AMADOR, Filomena. A História da Ciência em manuais escolares de Ciências da Natureza. Revista Electrónica de Enseñanza de las Ciencias. Vigo, v. 6, n. 1, p. 191-216, 2007.

29 LATOUR, Bruno; WOOLGAR, Steve. Laboratory Life. The construction of scientific facts. Princeton: Princeton University Press, 1986.

30 CHANG, Hasok. How Historical Experiments Can Improve Scientific Knowledge and Science Education: The Cases of Boiling Water and Electrochemistry. Science \& Education, v. 20, n. 3-4, p. 317-341, 2011; DUCHEYNE, Steffen. The Cavendish Experiment as a Tool for Historical Understanding of Science. Science \& Education, v. 21, n.1, p. 87-108, 2012; SICHAU, Chistian. Practising Helps: Thermodynamics, History, and Experiment. Science \& Education, v.9, n.4, p. 389-398, 2000; TEICHMANN, Jürgen. Studying Galileo at Secondary School: A Reconstruction of His 'Jumping-Hill' Experiment and the Process of Discovery. Science \& Education, v.8, n.2, p. 121-136, 1999.

[Recebido em Dezembro de 2013. Aprovado para publicação em Setembro de 2014] 